\title{
Pangasinan State University - School of Advanced Studies Graduates' Level of Satisfaction and Degree Programs' Contribution to their Professional and Personal Growth
}

\author{
*Christopher J. Cocal, Cristeta C. Dulos, and Rodelio P. Garin \\ Pangasinan State University - School of Advanced Studies, Philippines
}

DOI - http://doi.org/10.37502/IJSMR.2021.4707

\begin{abstract}
The study looked at how satisfied the graduates of the Pangasinan State University School of Advanced Studies were with their degree programs and how they contributed to their professional and personal growth. The descriptive research design was utilized with 239 graduates who were randomly selected as respondents to the study. The results of the study revealed that the graduates have a high level of satisfaction with the services and resources provided as well as with their professors' attributes, relationship with their professors and other students, and their thesis/dissertation experience. The degree program completed by the graduates were highly contributory to their professional and personal growth.
\end{abstract}

Keywords: Level of satisfaction, personal and professional growth, graduate studies, quality of instruction, employment status.

\section{Introduction}

Education and training systems play a critical role in ensuring that all persons have the opportunity to continuously expand their skills through lifelong learning, allowing them to adapt to quickly changing labor market requirements and conditions. The ultimate goal of graduate programs in the Philippines is to contribute to the process of knowledge acquisition, generation, sharing, and exchange that is distinct from the baccalaureate level (CMO 15, s. of 2019). The competencies of graduates of master's and doctoral programs are aligned with the Philippine Qualifications Framework under Level 7 and 8, respectively.

The age of globalization and digitization has created a tremendous demand for varied disciplines in education, taking into consideration the emerging competitive skills and competencies needed in this revolution. The cost of providing quality education has tremendously risen due to better teaching methodologies and approaches, learning instruments for assessments, instructional materials, and other resources and incentives for teachers.

As higher educational institutions go for internationalization, the evaluation of educational service quality is essential to provide motivation and give feedback on the effectiveness of educational programs and implementation. The extent to which students' needs and expectations are met can be used to measure education quality (Uysal, 2015). Students' satisfaction has become a significant challenge for universities and is being shaped continually by repeated experiences in campus life. Providing quality education and a constructive environment to students are factors that can influence their choices and satisfaction. Likewise, satisfying their needs and expectations, faculty competencies, classroom environment, learning facilities, and institution's reputation are factors considered by the students staying in the 
school. The evaluation of the efficiency and efficacy of the learning process requires an assessment of the perceived quality and related satisfaction for the university experience (Bertaccini et al., 2021). Further, graduates attributed their satisfaction with their university program both to the university's perceived quality and aspects of their program (Espinoza \& Mcginn, 2018).

Attending graduate and post-graduate school certainly can contribute to one's development and advancement (Gonzales et al., 2019). Schools must provide the training that meets the standards employers set for their workforce (Albina \& Sumagaysay, 2020). However, graduates from lower social classes have more varied and less stable career paths, are less likely to enter top-level positions in their 20s, and are more likely to enter and remain in lower social classes than their more socially advantaged peers, according to research. Some of these tendencies appear to be explained by the age at which persons graduate from HE. Surprisingly, HE criteria such as degree class, fields of study, and type of university attended only account for a portion of social class disparities (Duta et al., 2021). According to a recent study, experts considered some business-related hard skills (such as consumer psychology, business tactics, and marketing) essential both before and after COVID-19. Having a high level of business knowledge is advantageous for employability (Sato et al., 2021).

The labor markets in the Philippines and abroad have become very competitive. Reports from the Philippine Statistics Authority (PSA) showed that in October 2020, the employment rate in the Philippines was $91.3 \%$, with an $8.7 \%$ unemployment rate or an equivalent to 3.8 million unemployed Filipinos aged 15 and above. Moreover, 14.4\% were reported for underemployment.

When parents are confronted with the choice of universities and colleges where their children will attend and get a degree, the prospects for future employment carry much weight. Employability, thus, becomes a matter of crucial consideration when schools define their curriculum and their policies on recruitment, entrance, and retention (Albina \& Sumagaysay, 2020). Employability refers to the skills and qualities that make an individual desirable to potential employers (Pan \& Lee, 2011).

According to an international study, research and internationalization metrics and traits indicating institutions' readiness to invest in higher education and human resource development have been linked to high levels of employability (Aviso et al., 2021). While work experience during study allows graduates to build a preprofessional identity in which they can select and internalize the skills and behaviours required in their target professional pathway (Herbert et al., 2020), employability is not only associated with employment processes. It is also related to graduate students' academic publication and provides students and university perspectives on the potential benefits of improving employability (Pan \& Lee, 2011). Moreover, young professionals who have developed high levels of career competencies reported higher levels of perceived employability(Blokker et al., 2019). Researchers and policymakers, on the other hand, are unsure about graduate skills that meet workplace needs and promote employability (Suleman, 2016).

The PSU- School of Advanced Studies (SAS), formerly the Graduate School, is mandated to produce professionals and young leaders in various disciplines like education, engineering, agriculture, business management, public administration, and other developmentdriven professions. It is committed to engaging its faculty and students in advancing their knowledge and competencies to sustain better research and instructional delivery practices. 
Every year, the PSU-SAS produces graduates in different disciplines, and these graduates are hoping for better and more opportunities in the field. These opportunities necessitate the standards expected of the position/designation it offers, and having been garnered advanced studies means more qualified, better professionals and competent leaders in the different agencies.

Therefore, to determine how the PSU-SAS is doing its mandates, there is a felt need to conduct a tracer study of its graduates from 2016-2019. Tracer studies provide information that is useful to all educational actors. These data can be used to inspire education, training and employment policies, as well as curriculum for education and training courses, counselling to help individuals choose their educational or training pathways, and sharper judgment regarding labor force skills.

The study was conducted to determine the profile, degree program completed, and length of stay in the PSU - SAS to finish their degree programs of the graduates from 2016 to 2019. Further, the study determined the level of satisfaction of the graduates along the different services offered, the attributes of the professors, and the quality of instruction, their relationship with their professors and classmates, their experiences in doing their thesis/dissertation, the employment status of the graduates and the relevance of their acquired knowledge and skills in their job. More importantly, the study determined the contribution of their degree program to their personal and professional growth and employment status.

As a graduate survey, results of the study will serve as a guidepost to the administration for a basis for sound planning, decision-making, and further improvement its curricular programs and operations, particularly on the training content and study conditions, improving the transition of graduates from education to the labor market, and to better matching the supply of skills with the demand of the market.

\section{Methods}

\section{Research Design}

The study made used of the descriptive-survey research design as the study determined the profile of the graduates, their level of satisfaction with the resources, experiences, and services provided by the School of Advanced Studies, the contribution of the graduate degrees to their professional and personal growth, and their employment status.

\section{Subject, respondents, and sampling}

A total of 239 graduates from the various degree programs offered by SAS served as respondents of the study. Cluster random sampling was utilized in the distribution of samples.

\section{Data Collection}

The data were collected with the use of google form which was sent to the graduates.

\section{Data Analysis}

The data were analyzed using descriptive statistical tools such as frequency and percentage and average weighted mean.

\section{Results}

\section{Profile of the Graduates}


Presented in Table 1 is the profile of the graduates in terms of sex, age, civil status, degree finished in SAS, and the number of years to finish the degree.

As presented in Table 1, 59.83\% of the graduate respondents were females, with $33.47 \%$ males. The study results showed that the School of Advanced Studies caters significantly to the educational advancement of women professionals. The result could be attributed to the degree programs offered in SAS, which are more on teacher education. Numerous studies have shown that the teaching profession is still dominated by women

Table 1. Profile of the Graduates $(n=239)$.

\begin{tabular}{l|l|c|c}
\hline Variable & Group & Frequency & Percentage \\
\hline Sex & Male & 80 & 33.47 \\
& Female & 143 & 59.83 \\
& Non-response & 16 & 6.69 \\
\hline Age & Early Working age (24) & 6 & 2.51 \\
& Prime Working Age (25 - 54) & 186 & 77.82 \\
& Mature Working Age (55-62) & 7 & 2.93 \\
& Non-response & 40 & 16.74 \\
& & & \\
\hline Civil Status & Single & 114 & 47.70 \\
& Married & 100 & 41.84 \\
& Separated & 6 & 2.51 \\
& Widowed & 18 & 0.42 \\
& Non-response & 176 & 7.53 \\
& & 63 & 73.64 \\
\hline Degree Finished & Masteral & 84 & 36.36 \\
\hline rrom SAS & Doctoral & 107 & 44.77 \\
\hline Sumber of Years & At most 3 years & 25 & 10.46 \\
& More than 3 to 5 years & 23 & 9.62 \\
\hline
\end{tabular}

With respect to the ages of the graduate-respondents, $77.82 \%$ belong to the age bracket $25-54$, which is categorized as prime working age. The age bracket is also the ideal age to pursue graduate studies.

In terms of civil status, $47.70 \%$ of the graduate respondents were single, while $41.84 \%$ were married. The study results showed that pursuing graduate studies is a greater priority among professionals due to the increasing competition and higher requirements for promotions in the various fields and industries.

With respect to the degrees graduated. $73.64 \%$ finished master's degrees, with $26.36 \%$ finished doctorate degrees. Further, $35.15 \%$ finished their respective degrees in utmost three years while $44.77 \%$ in $3-5$ years. It has to be noted that in the Philippines, a master's degree is expected to be completed in 3 years, while doctorate degrees are in $4-5$ years. Results showed that the majority of the graduate respondents finished their respective degrees within the expected time frame. 


\section{Level of Satisfaction of the Graduates on the Different Services}

Table 2 presents the level of satisfaction of the graduate respondents on the registrar and cashier services of the School of Advanced Studies.

Table 2. Level of Satisfaction on Registrar and Cashier Services

\begin{tabular}{|c|c|c|}
\hline Indicator & AWM & Description \\
\hline Registrar's Services & 3.95 & Highly Satisfied \\
\hline Cashier's Services & 3.78 & Highly Satisfied \\
\hline Overall Mean & 3.87 & Highly Satisfied \\
\hline
\end{tabular}

$1.0-1.50$ - Not satisfied; $1.51-2.50$ - Least satisfied; $2.51-3.50$ - Moderately satisfied; $3.51-4.50$ - Highly satisfied; $4.51-5.0$ - Very highly satisfied

The results of the study showed that the graduate respondents were highly satisfied with the services provided by the Offices of the Registrar and Cashier as manifested by the average weighted mean values of 3.95 and 3.78 respectively. The high satisfaction of the graduate respondents is a manifestation that the Offices of the Registrar and Cashier offers quality services among their clientele and uphold the university's core value, which is excellent service delivery.

The study results showed that the graduate respondents were highly satisfied with regards to students' resources available in the School of Advanced Studies. Among the different resources, the graduate respondents were satisfied the most with the instructional resources. The average weighted mean value of 4.05 was computed, descriptively rated as highly satisfied.

Table 3. Level of Satisfaction on Students' Resources

\begin{tabular}{|c|c|c|}
\hline Indicator & AWM & Description \\
\hline Instructional Resources & 4.05 & Highly Satisfied \\
\hline Library Resources & 3.71 & Highly Satisfied \\
\hline IT/Technology Resources & 3.72 & Highly Satisfied \\
\hline Overall Mean & 3.83 & Highly Satisfied \\
\hline
\end{tabular}

1.0 - 1.50 - Not satisfied; $1.51-2.50$ - Least satisfied; 2.51 - 3.50 - Moderately satisfied; $3.51-4.50$ - Highly satisfied; $4.51-5.0$ - Very highly satisfied

As reflected in Table 4, the graduate respondents were highly satisfied with the attributes of their professors and highly satisfied with the quality of instruction received by them. Among the different indicators, the graduate respondents were satisfied the most with their professors' knowledge of the subjects being taught, followed by their pedagogical expertise. Average weighted mean values of 4.62 and 4.56 were computed, respectively, descriptively rated as very highly satisfied. 
Table 4. Level of Satisfaction on Professors' Attributes and Quality of Instruction

\begin{tabular}{|c|c|c|}
\hline Indicator & AWM & Description \\
\hline $\begin{array}{l}\text { Professors' Knowledge of the subject } \\
\text { matter }\end{array}$ & 4.62 & Very Highly Satisfied \\
\hline Professors' Pedagogical Expertise & 4.56 & Very Highly Satisfied \\
\hline $\begin{array}{l}\text { Range of knowledge acquired for the } \\
\text { enrolled courses/subjects }\end{array}$ & 4.47 & Highly Satisfied \\
\hline Quality of instructions & 4.47 & Highly Satisfied \\
\hline Class size & 4.04 & Highly Satisfied \\
\hline Overall Mean & 4.43 & Highly Satisfied \\
\hline
\end{tabular}

$1.0-1.50$ - Not satisfied; $1.51-2.50$ - Least satisfied; $2.51-3.50$ - Moderately satisfied; $3.51-4.50$ - Highly satisfied; $4.51-5.0$ - Very highly satisfied

The study results showed that there is still room for improvements on the attributes of the professors teaching in the School of Advanced Studies and the quality of instruction being provided to the students.

Table 5. Level of Satisfaction on Professors' and Students' Professional Relationships

\begin{tabular}{c|c|c}
\hline \multicolumn{1}{c|}{ Indicator } & AWM & Description \\
\hline $\begin{array}{c}\text { Professor - student working/teaching } \\
\text { relationships }\end{array}$ & 4.46 & Highly Satisfied \\
Student-student relationship & 4.42 & Highly Satisfied \\
\hline Overall Mean & 4.44 & Highly Satisfied \\
\hline
\end{tabular}

$1.0-1.50$ - Not satisfied; $1.51-2.50$ - Least satisfied; $2.51-3.50$ - Moderately satisfied; $3.51-4.50-$ Highly satisfied; $4.51-5.0-$ Very highly satisfied

Regarding professor-student working/teaching relationships and student-student relationships, the graduate respondents were highly satisfied as manifested by the mean values of 4.46 and 4.42, respectively. The result is indicative that the professors and graduate students in the School of Advanced Studies are very professional and collegial in dealing with each other.

Table 6. Level of Satisfaction on Thesis/Dissertation Experience

\begin{tabular}{l|c|c}
\hline \multicolumn{1}{c|}{ Indicator } & AWM & Description \\
\hline Knowledge/Expertise of your adviser & 4.66 & Very Highly Satisfied \\
Technical Expertise / Knowledge of the Panel & 4.63 & Very Highly Satisfied \\
$\quad$ of Examiners & 4.61 & Very Highly Satisfied \\
Assistance Provided by your adviser & 4.61 & Very Highly Satisfied \\
Technical Expertise and Knowledge of your & & \\
$\quad$ Critic Reader & 4.56 & Very Highly Satisfied \\
Assistance provided by your Critic Reader & 4.50 & Very Highly Satisfied \\
Manner of the conduct of defense & 4.39 & Highly Satisfied \\
Scheduling of your defense & 4.57 & Very Highly Satisfied \\
\hline \multicolumn{2}{c}{ Overall Mean } &
\end{tabular}

$1.0-1.50$ - Not satisfied; $1.51-2.50$ - Least satisfied; $2.51-3.50$ - Moderately satisfied; $3.51-4.50$ - Highly satisfied; $4.51-5.0$ - Very highly satisfied

As presented in Table 6, the graduate - respondents were very highly satisfied with their thesis/dissertation experiences, as manifested by the overall mean value of 4.57. Among 
the different indicators, the graduate - respondents were most satisfied with the knowledge/expertise of their assigned adviser, followed by the technical expertise/knowledge of their assigned panel members. Average weighted mean values of 4.66 and 4.63 were computed, respectively, descriptively rated as very highly satisfied. On the other hand, the graduate - respondents were highly satisfied with the scheduling of their defense. The average weighted mean value of 4.39 was computed, descriptively rated as highly satisfied.

The high level of satisfaction of the graduates on the services and experiences in the School of Advanced Studies is a manifestation that SAS provides quality education to the graduate students that promote their professional growth and development.

\section{Level of Contribution of the Degree Obtained From SAS to the Graduates' Professional and Personal Growth}

Table 7 presents the level of contribution of the degree obtained from SAS to their professional and personal growth.

Table 7. Level of Contribution of the Degree Obtained from SAS to the Graduates' Professional and Personal Growth

\begin{tabular}{l|c|c}
\hline \multicolumn{1}{c|}{ Indicator } & $\begin{array}{c}\text { Average } \\
\text { Weighted } \\
\text { Mean }\end{array}$ & Description \\
\hline 1. Opportunities for Professional Growth & 4.51 & Very Highly Contributory \\
2. Academic mastery & 4.47 & Highly Contributory \\
3. Learning Efficiency & 4.47 & Highly Contributory \\
4. Communication Skills & 4.42 & Highly Contributory \\
5. Present and Future Professional Needs' & 4.37 & Highly Contributory \\
$\quad$ Sustainability & 4.27 & Highly Contributory \\
6. Promotion, Incentives & 4.24 & Highly Contributory \\
7. Problem-Solving Skill & 4.23 & Highly Contributory \\
8. Research Capability & 4.14 & Highly Contributory \\
9. Information Technology Competency & 4.13 & Highly Contributory \\
10. Partnership and Linkages & 4.32 & Highly Contributory \\
\hline
\end{tabular}

$1.0-1.50$ - Not contributory; $1.51-2.50$ - Least contributory; $2.51-3.50$ - Moderately contributory; $3.51-4.50$ - Highly contributory; $4.51-5.0$ - Very highly contributory

Results of the study showed that the degree graduated from the School of Advanced Studies was highly contributory to the graduates' professional and personal growth as manifested by the overall mean value of 4.32 . The greatest contribution was observed in their opportunities for professional growth. The average weighted mean value of 4.51 was computed, descriptively rated as very highly contributory. Academic mastery and learning efficiency followed with average weighted mean values of 4.47 respectively, descriptively rated as highly contributory. On the other hand, earning a degree from SAS has the least contribution to the graduates' professional and personal growth and partnership, linkages, and IT competency. Average weighted mean values of 4.13 and 4.14 were computed, respectively, descriptively rated as highly contributory. 
It has to be noted that the main reason why professionals pursue graduate studies is to advance their professional and personal growth and development since a graduate degree will lead to higher qualifications and better employment. With the results of the study, it can be said the Pangasinan State University School of Advanced Studies contributes to the promotion of professional and personal growth of professionals that makes them become more globally competent.

Table 8. Employment Profile of the Graduates

\begin{tabular}{l|l|c|c}
\hline & Variable & Frequency & Percent \\
\hline & Self/not employed & 2 & 0.8 \\
& Job Order & 1 & 0.4 \\
& Casual & 1 & 0.4 \\
Employment Status & Probationary & 6 & 2.5 \\
& Contractual & 34 & 14.2 \\
& Temporary & 10 & 4.2 \\
& Permanent & 185 & 77.4 \\
\hline \multirow{5}{*}{ Type of } & Unemployed & 3 & 1.3 \\
Organization & Private non-academe & 3 & 1.3 \\
Employed & Private Academe & 48 & 20.1 \\
& Public non-academe & 6 & 2.5 \\
\hline \multirow{5}{*}{ Number of Years in } & Public Academe & 179 & 74.9 \\
Service & $1-5$ & 110 & 46 \\
& $6-10$ & 65 & 27 \\
& $11-15$ & 23 & 10 \\
& $16-20$ & 16 & 7 \\
& $21-25$ & 15 & 6 \\
& $26-30$ & 5 & 2 \\
& $31-35$ & 2 & 0.8 \\
\hline
\end{tabular}

The results of the study showed that almost all of the graduates were already employed while pursuing graduate studies, as shown in Table 38. Further, the majority (77.4\%) were of permanent status, with $74.9 \%$ working in public and $2.5 \%$ in private academic institutions. Moreover, $95.8 \%$ of the graduates disclosed that their degree program taken from the School of Advanced Studies is related to their current job. As reiterated, the School of Advanced Studies caters greatly to the needs for graduate studies of professional teachers.

In terms of the number of years in service, $46 \%$ of the graduates have been working for $1-5$ years while $27 \%$ for $6-10$ years. The study results show that the graduates are newly employed or have been working for a short period of time. The graduates are still in the process of establishing their selves in their chosen career or profession. 
Table 9. Length of Time Needed to Find Employment after Graduating From SAS $(\mathbf{n}=16)$

\begin{tabular}{|c|c|c|}
\hline Period & Frequency & Percent \\
\hline Still not employed & 2 & 12.5 \\
\hline 36 months and above & 3 & 18.8 \\
\hline $24-35$ months & 1 & 6.3 \\
\hline $12-23$ months & 2 & 12.5 \\
\hline $6-11$ months & 2 & 12.5 \\
\hline 1 day - 5 months & 6 & 37.5 \\
\hline Total & 16 & 100 \\
\hline
\end{tabular}

Note: The data reflected pertains to those who are not yet employed while taking graduate studies at SAS.

Presented in Table 9 is the length of time it took for the graduates to land a job after graduation. As presented, 6 of the graduates could find a job within $1-5$ months after graduation. Others took six months or more. It has to be noted that almost all of the graduates were already employed while taking graduate studies. However, data shows that even after acquiring a graduate degree, finding a job is still not easy for other people. This could be attributed to the intense competition in the labor market in the Philippines.

\section{Discussion}

The study intends to determine the profile, level of satisfaction on the different services provided by SAS, and contribution of the degree programs to their personal and professional growth. The study included the profile of the graduates and the number of years it took them to complete their respective degrees.

Since most of the program offerings in the PSU School of Advanced Studies are in line with teacher education which is female-dominated, the graduate students of SAS are also female-dominated. On the other hand, the graduate students of PSU - SAS generally belong to the age bracket $21-59$. Most of them are working as teachers, while others are school heads or school principals. The teachers and other professionals are taking graduate studies for promotion or to land better job opportunities in the Philippines or abroad. According to the stages of human growth and development, individuals aged $20-39$ or young adults are in the process of solidifying their lifelong bonds. Many enter committed relationships or marriages, while others form lifelong friendships. A lot are establishing their careers. On the other hand, those aged $40-59$ or the middle adults are struggling with their contribution to society. A middle-aged adult raising a family and working in a profession that presumably benefits people may feel more fulfilled than an adult who is working at a day job that feels meaningless.

Based on CMO 15, series of 2019, master's degrees will be completed within seven years and nine years for doctoral degrees. The study results reveal that the graduate students finish their degree programs within the expected time frame. Further, more professionals are finishing master's degrees as compared to doctorate degrees. Completing a doctorate degree is more difficult than a master's degree.

Learning environments play an important role in students' learning and outcomes (Maulana et al., 2016). In like manner, school facilities have an important role in ensuring the quality of teaching and learning with respect to achieving quality of education. The qualities of school facilities have a significant impact on student performance (Hasbullah et al., 2011; Ibrahim et al., 2016) and teacher effectiveness. These facilities provided extra learning and 
leisure opportunities for the whole school community(Ibrahim et al., 2016). With school facilities and their components being significantly related to students' academic performance, schools must strive to improve the status of their facilities. The results of the study revealed that PSU - SAS provides the resources needed by the graduate students that are essential in their learning process. This in return has resulted to the high satisfaction of the graduate students on the services provided to them by the PSU-SAS.

Competitive graduates in the job market often depend on strong curriculum of the programs. A strong program structure is important to ensure that graduates acquire enough knowledge and also essential in supporting graduates in searching for a job after they graduate (Ahmad et al., 2012). Results of the study affirm that of Gonzales, et al. (2019) wherein, graduates of the School of Advanced Studies believed that they received better service delivery along with the learning environment, particularly on teaching staff's knowledge, interaction, creativity, respect for students and delivery skills.

Employability, thus, becomes a matter of crucial consideration when schools define their curriculum and their policies on recruitment, entrance, and retention (Albina \& Sumagaysay, 2020). Employability refers to the skills and qualities that make an individual desirable to potential employers (Pan \& Lee, 2011). Accordingly, young professionals with high levels of career competencies perceived higher levels of employability(Blokker et al., 2019).

Attending graduate and post-graduate school certainly can contribute to one's development and advancement (Gonzales et al., 2019). Schools have to provide the training that meets the standards employers set for their workforce (Albina \& Sumagaysay, 2020). While work experience during study allows graduates to build a preprofessional identity in which they can select and then internalize the skills and behaviours required in their target professional pathway (Herbert et al., 2020). The results of the study manifests that the degree completed by the students in SAS has contributed to their personal and professional growth and development.

\section{Limitations}

One of the limitations of the study is the number of respondents or the graduates who have participated in the study. To make a tracer study more comprehensive, greater participation form the graduate population is recommended.

\section{References}

1) Commission on Higher Education Memorandum Order 15, series of 2019

2) Uysal, F. (2015). Evaluation of the Factors That Determine Quality in Graduate Education : Application of a Satisfaction Benchmarking Approach. Procedia - Social and Behavioral Sciences, 191, 1034-1037. https://doi.org/10.1016/j.sbspro.2015.04.386

3) Bertaccini, B., Bacci, S., \& Petrucci, A. (2021). A graduates' satisfaction index for the evaluation of the university overall quality. Socio-Economic Planning Sciences, 73. https://doi.org/10.1016/j.seps.2020.100875

4) Espinoza, O., \& Mcginn, N. (2018). Graduates' satisfaction as a measure of quality: Evidence from two programs in three Chilean universities. International Journal of Educational Research, 90(May), 133-143. https://doi.org/10.1016/j.ijer.2018.05.009

5) Gonzales, R. D., Bautista, A. S., \& Gelido, R. T. (2019). Work Status of Alumni and their Satisfaction on Selected Indicators in the School of Advanced Studies (SAS). World Journal of Education, 9(2), 56. https://doi.org/10.5430/wje.v9n2p56

6) Albina, A. C., \& Sumagaysay, L. P. (2020). Employability tracer study of Information Technology Education graduates from a state university in the Philippines. Social Sciences \& Humanities Open, 2(1), 100055. https://doi.org/10.1016/j.ssaho.2020.100055 
7) Duta, A., Wielgoszewska, B., \& Iannelli, C. (2021). Different degrees of career success: social origin and graduates' education and labour market trajectories. Advances in Life Course Research, 47. https://doi.org/10.1016/j.alcr.2020.100376

8) Sato, S., Kang, T. A., Daigo, E., Matsuoka, H., \& Harada, M. (2021). Graduate employability and higher education's contributions to human resource development in sport business before and after COVID-19. Journal of Hospitality, Leisure, Sport and Tourism Education, 28. https://doi.org/10.1016/j.jhlste.2021.100306

9) Albina, A. C., \& Sumagaysay, L. P. (2020). Employability tracer study of Information Technology Education graduates from a state university in the Philippines. Social Sciences \& Humanities Open, 2(1), 100055. https://doi.org/10.1016/j.ssaho.2020.100055

10) Pan, Y.-J., \& Lee, L.-S. (2011). Academic Performance and Perceived Employability of Graduate Students in Business and Management - An Analysis of Nationwide Graduate Destination Survey. Procedia - Social and Behavioral Sciences, 25, 91-103. https://doi.org/10.1016/j.sbspro.2011.10.531

11) Aviso, K. B., Demeterio, F. P. A., Janairo, J. I. B., Lucas, R. I. G., Promentilla, M. A. B., Tan, R. R., \& Yu, D. E. C. (2021). What university attributes predict for graduate employability? Cleaner Engineering and Technology, 2, 100069. https://doi.org/10.1016/j.clet.2021.100069

12) Herbert, I. P., Rothwell, A. T., Glover, J. L., \& Lambert, S. A. (2020). Graduate employability, employment prospects and work-readiness in the changing field of professional work. International Journal of Management Education, 18(2). https://doi.org/10.1016/j.ijme.2020.100378

13) Pan, Y.-J., \& Lee, L.-S. (2011). Academic Performance and Perceived Employability of Graduate Students in Business and Management - An Analysis of Nationwide Graduate Destination Survey. Procedia - Social and Behavioral Sciences, 25, 91-103. https://doi.org/10.1016/j.sbspro.2011.10.531

14) Blokker, R., Akkermans, J., Tims, M., Jansen, P., \& Khapova, S. (2019). Building a sustainable start: The role of career competencies, career success, and career shocks in young professionals' employability. Journal of Vocational Behavior, 112, 172-184. https://doi.org/10.1016/j.jvb.2019.02.013

15) Maulana, R., Opdenakker, M., \& Bosker, R. (2016). Teachers' instructional behaviors as important predictors of academic motivation: Changes and links across the school year. Learning and Individual Differences, 50, 147-156. https://doi.org/10.1016/j.lindif.2016.07.019

16) Hasbullah, A., Zahari, W., Yusoff, W., Ismail, M., \& Vitasari, P. (2011). A framework study of school facilities performance in public primary school of Batubara district in Indonesia. Procedia - Social and Behavioral Sciences, 15, 3708-3712. https://doi.org/10.1016/j.sbspro.2011.04.360

17) Ibrahim, N. M., Osman, M. M., Bachok, S., \& Zin, M. (2016). Assessment on the Condition of School Facilities : Case study of the selected public schools in Gombak district. Procedia - Social and Behavioral Sciences, 222, 228-234. https://doi.org/10.1016/j.sbspro.2016.05.151

18) Ibrahim, N. M., Osman, M. M., Bachok, S., \& Zin, M. (2016). Assessment on the Condition of School Facilities : Case study of the selected public schools in Gombak district. Procedia - Social and Behavioral Sciences, 222, 228-234. https://doi.org/10.1016/j.sbspro.2016.05.151

19) Ahmad, K., Zainal, N. F. A., Idris, S., \& Rahmat, M. (2012). Relationship between Employability and Program Outcomes Achievement. Procedia - Social and Behavioral Sciences, 59, 254-263. https://doi.org/10.1016/j.sbspro.2012.09.273 
20) Gonzales, R. D., Bautista, A. S., \& Gelido, R. T. (2019). Work Status of Alumni and their Satisfaction on Selected Indicators in the School of Advanced Studies (SAS). World Journal of Education, 9(2), 56. https://doi.org/10.5430/wje.v9n2p56

21) Albina, A. C., \& Sumagaysay, L. P. (2020). Employability tracer study of Information Technology Education graduates from a state university in the Philippines. Social Sciences \& Humanities Open, 2(1), 100055. https://doi.org/10.1016/j.ssaho.2020.100055

22) Pan, Y.-J., \& Lee, L.-S. (2011). Academic Performance and Perceived Employability of Graduate Students in Business and Management - An Analysis of Nationwide Graduate Destination Survey. Procedia - Social and Behavioral Sciences, 25, 91-103. https://doi.org/10.1016/j.sbspro.2011.10.531

23) Technology, 2, 100069. https://doi.org/10.1016/j.clet.2021.100069

24) Blokker, R., Akkermans, J., Tims, M., Jansen, P., \& Khapova, S. (2019). Building a sustainable start: The role of career competencies, career success, and career shocks in young professionals' employability. Journal of Vocational Behavior, 112, 172-184. https://doi.org/10.1016/j.jvb.2019.02.013

25) Gonzales, R. D., Bautista, A. S., \& Gelido, R. T. (2019). Work Status of Alumni and their Satisfaction on Selected Indicators in the School of Advanced Studies (SAS). World Journal of Education, 9(2), 56. https://doi.org/10.5430/wje.v9n2p56

26) Albina, A. C., \& Sumagaysay, L. P. (2020). Employability tracer study of Information Technology Education graduates from a state university in the Philippines. Social Sciences \& Humanities Open, 2(1), 100055. https://doi.org/10.1016/j.ssaho.2020.100055

27) Herbert, I. P., Rothwell, A. T., Glover, J. L., \& Lambert, S. A. (2020). Graduate employability, employment prospects and work-readiness in the changing field of professional work. International Journal of Management Education, 18(2). https://doi.org/10.1016/j.ijme.2020.100378 